\title{
Internal and External Audit Attributes, Audit Committee Characteristics, Ownership Concentration and Earnings Quality: Evidence from Malaysia
}

\author{
Ahmed Hussein Al-Rassas \\ College of Business, Universiti Utara Malaysia, 06010 UUM Sintok, Kedah Malaysia \\ Email: aalrasas@gmail.com \\ Hasnah Kamardin \\ College of Business, Universiti Utara Malaysia, 06010 UUM Sintok, Kedah Malaysia \\ Email: hasnahk@uum.edu.my
}

\section{Doi:10.5901/mjss.2015.v6n3p458}

\begin{abstract}
The objective of the study is to examine the association between internal and external audit attributes, audit committee characteristics, ownership concentration and discretionary accruals (as a proxy of earnings quality) based on the agency and resource dependence theories. The final sample of the study is 508 firms listed on the Malaysia Main Market from 2009 to 2012. Two measures of discretionary accruals are used, Modified Jones model by Dechow et al. (1995); and extended Modified Jones Model by Yoon et al. (2006). Results of the study suggest that outsourcing internal audit function, investment in internal audit function and external audit fees are related to higher earnings quality. However, large audit committee size, more frequent audit committee meetings, having a senior or former audit partner as audit committee chairman and ownership concentration are associated with lower earnings quality. This study extends the prior related literature by apply extended modified Jones model by Yoon, et al.'s (2006) of discretionary accruals to measure earnings quality in Malaysia Main Market listed companies and introduce new variables, namely audit committee chairman who is a senior or former audit partner in the audit firm.
\end{abstract}

Keywords: Audit committee, audit fees, internal audit function, ownership concentration, discretionary accruals, earnings quality, Malaysia.

\section{Introduction}

With the recent high-profile scandals in accounting, investors have become concerned with earnings management and have begun to demand for earnings quality for the purpose of enhancing financial statement quality (Bedard \& Johnstone, 2004). Certain aspects, such as discretionary accruals, have received much attention as an important indicator of earnings quality. High earnings quality, financial reporting transparency and auditing are important to gain investors' and other stakeholders' confidence.

Earnings management is reflected in earnings quality, whereby greater earnings management results in lower earnings quality and vice versa. Management engages in earnings management for many reasons, among them being to reduce political costs (Warfield, Wild \& Wild, 1995), to avoid default in debt covenant (Klein, 2002; Davidson, GoodwinStewart \& Kent, 2005) and to increase manager's wealth (Radzi, Islam\& Ibrahim, 2011).

The purpose of the study is to examine the influence of internal and external audit as governance monitoring mechanisms because they are responsible for evaluating the quality of financial reporting. The audit committee is considered as one of the pillars of accountability because it supports the boards' role to monitor the process of financial reporting while the function of internal and external audit supports the function of the audit committee through auditors' reports. Simunic (1984) argues that the provision of external non-audit services leads to high audit quality. Thus, companies that engage external auditors to carry out non-audit services will have less accounting risks than companies that do not engage such services.

This study extends the prior related literature by several ways. First, this study is the first study to apply Yoon, Miller and Jiraporn's (2006) model of discretionary accruals to measure earnings quality of companies listed on the Malaysian Main Market. Second, we introduce new variables, namely audit committee chairman who is a senior or former audit partner in the audit firm. Third, following the previous studies (Porta, Lopez-De-Silanes \& Shleifer, 1999; Fan \& 
Wong, 2002; Yunos, Smith \& Ismail, 2010; Kamardin \& Haron, 2011; Abdullah \& Nasir (2004); Abdul Rahman \& Ali 2006) suggestions of the effect of ownership concentration on monitoring mechanisms, information asymmetry and its impact on earnings quality, we also examine ownership concentration (five largest shareholders) on earnings quality of companies listed on the Malaysian Main Market.

\section{Literature Review and Hypotheses Development}

The Malaysian government took certain measures as proposed by the regulatory bodies and accountancy professions to alleviate the occurrence of fraud and fraudulent financial reporting. This resulted in the implementation of the Malaysian Code on Corporate Governance in March 2000. This code covers four areas, i.e., board of directors, accountability, shareholders and remuneration of directors. The revision of the Code was done in 2007 (known as the MCCG 2007), to allow for greater internal monitoring control. The function of an internal auditor, who directly reports to the audit committee, is to recognise and manage risks (Hassan, Moyes, Mohd-Sanusi \& Iskandar, 2010). In addition, the Malaysian Code on Corporate Governance (revised again in 2012 and known as MCCG 2012) pays greater attention to the composition and structure of the board, where the directors' role is recognized as active and responsible fiduciaries. Directors should ensure that the governance structure is effective in order to enable risk and internal control management.

\subsection{Audit Committee Size}

According to the resource dependence theory, a larger audit committee means the members can bring more resources to the firm, such as experience and expertise, which contribute to the audit committee's effectiveness in monitoring management, hence leading to high earnings quality. The Cadbury Report (1992) and the Smith Report (2003) stipulate the number of audit committee members must be at least three; the Sarbanes-Oxley Act (2002) also mandates a minimum of three members in the audit committee. Buchalter and Yokomoto (2003) recommend that audit committees should be composed of three to five members although it is generally based on the firm's size. The Malaysian Code on Corporate Governance recommends there should be at least three non-executive directors in the audit committee, a majority of whom should be independent.

Empirical studies provide evidence that audit committee size is related to high earnings quality (Garcia, Barbadillo \& Perez, 2010; Lin, Li \& Yang, 2006). Additional evidence from Malaysia by Ahmad-Zaluki and Wan-Hussin (2010); and Ismail, Adibah, Dunstan and Zijl (2009) find a significantly positive relationship between audit committee size and earnings quality. However, Abbott, Parker, Peters and Raghunandan (2003); Abbott, Parker and Peters (2004); Xie, Davidson and DaDalt (2003); Baxter and Cotter (2009); and Adiguzel (2013) find an insignificant association between audit committee size and earnings quality.

Following the resource dependence theory, it is predicted that the appointment of many audit committee members contributes to efficient internal monitoring and better earnings quality. Thus, we hypothesize that:

\section{$H_{1}:$ Audit committee size is negatively associated with discretionary accruals}

\subsection{Audit Committee Independence}

From the agency theory perspective, the effectiveness of audit committee is based on its characteristics (Ika \& Ghazali, 2012; Klein, 2002; Garcia, Barbadillo \& Perez, 2012; Vafeas, 2005). For the audit committee to achieve its functions, itsmembers should be independent from the management (Ismail et al., 2009; Krishnamoorthy, 2002). Lin, Li and Yang (2006) argue that an audit committee with majority of independent members can effectively monitor the management and reduce the opportunity for fraudulent reporting because there is less interference from the management.

Mustafa and Yusof (2010) argue that the independence of directors results in high financial reporting quality. Several empirical studies have shed light on the effectiveness of audit committee independence. Klein (2002) shows that audit committee independence is related to decreased abnormal accruals (proxy of earnings quality). Yang and Krishnan (2005); and Yunos (2011) find that audit committee independence is related to less discretionary accruals. Audit committee independence is also related to higher earnings quality (Bradbury, Mak \& Tan, 2006; Garcia et al., 2012) and quality financial reporting (Agrawal \& Chadha, 2005; Bedard \& Johnstone, 2004; Klein, 2002; Siagian \& Tresnaningsih, 2011). Some studies report an insignificant association between audit committee independence and earnings informativeness (Petra, 2007); discretionary accruals (Xie et al., 2003; Garcia et al., 2010; Adiguzel, 2013); and accrual 
quality (Baxter \& Cotter, 2009).

In relation to Malaysian studies, Saleh, Iskandar \& Rahmat (2007); and Mansor, Ch-Ahmad, Ahmad-Zaluki and Osman (2013) report a negative relationship between audit committee independence and earnings management; while Ahmad Zaluki and Wan Hussin (2010) show a positive association. On the other hand, some studies find no significant association between the independence of audit committee and earnings quality (Abdul Rahman \& Ali, 2006; Abdullah \& Nasir, 2004; Ismail et al., 2009). Based on the agency theory, we predict that an independent audit committee will be able to monitor management behaviour to manage earnings. Thus we hypothesize that:

$\mathrm{H}_{2}$ : Audit committee independence is negatively associated with discretionary accruals

\subsection{Audit Committee Meeting}

Bursa Malaysia emphasizes that the audit committee should meet at least four times annually. The frequency of audit committee meetings is a reflection of its effectiveness; the directors' experience and expertise can enhance internal monitoring functions (Zaman, Hudaib \& Haniffa, 2011). In relation to earnings quality, Garcia et al. (2010) find evidence that frequency of audit committee meetings is related to high earnings quality. Xie et al. (2003); and Garcia, et al. (2010) find frequency of audit committee meetings decreases the level of discretionary accruals. Saleh et al. (2007); and Yusof (2010) reveal a negative association between earnings management and meeting frequency of audit committees in Malaysia. Another study in the U.S. by Goh (2009) reveals that audit committee meeting frequency relates positively to timelier remediation of material weaknesses. However, some studies find no relationship between frequency of audit committee meetings and earnings quality (Baxter \& Cotter, 2009; Abdul Rahman \& Ali, 2006; Mohamad, Rashid \& Shawtari, 2012). Thus, we hypothesize that:

\section{$H_{3}:$ The frequent meeting of audit committee is negatively associated with discretionary accruals}

\subsection{Audit Committee Financial Expertise}

Financial expertise is very important for audit committee effectiveness to enhance the integrity of financial reporting quality. The Malaysian Code on Corporate Governance recommends that at least one of the audit committee members must have financial expertise. Xie et al. (2003); Baxter and Cotter (2009); and Chen and Zhou (2007) find evidence that financial expertise in audit committees decreases discretionary accruals. With regards to Malaysian companies, Saleh et al. (2007); and Yusof (2010) find audit committee financial expertise leads to high earnings quality .On the other hand, Mohamad et al. (2012) find no relationship between audit committee financial expertise and earnings quality. Based on the agency and resource dependence theories, we argue that audit committee financial expertise reduces discretionary accruals and enhances earnings quality. Thus, we hypothesize that:

\section{$H_{4}$ : Audit committee financial expertise is negatively associated with discretionary accruals}

\subsection{Audit Committee's Chairman Being Former Audit Partner}

The resource dependence theory proposes that a firm's directors who have knowledge and expertise bring important resources to the company which lead to increasing the firm's internal monitoring and enhancing financial reporting quality (Hillman \& Dalziel, 2003). Likewise, a former audit partner in the audit committee can be an expert who can help to increase the audit committee's internal monitoring effectiveness because he or she has experience in auditing, internal control and financial statements (Naiker \& Sharma, 2009). Naiker and Sharma (2009) examined the relationship between former audit partners on the audit committee and internal control deficiencies and find a negative relationship. However, another study by Menon and Williams (2004) finds that firms having a former audit partner as officers or directors are associated with larger accruals, thus suggesting a potential threat to audit independence. A study in Malaysia by Yusof (2010) finds former senior audit managers/partners are associated with larger discretionary accruals. Therefore, the chairman position could be the most influence factor. Accordingly, this study aims to provide empirical evidence about audit committees' chairman former audit partner which unexplored issue. Thus we hypothesize that: 


\subsection{Investment in Internal Audit Function}

According to the agency theory, an increase in the internal control system could lead to an increase in the monitoring process of the company to reinforce and increase the financial information outcomes (Jensen \& Meckling, 1976). Internal audit function has become a crucial internal monitoring mechanism in corporate governance (Al-Shetwi, Ramadili, Chowdury \& Sori, 2011). Prawitt, Smith and Wood (2009) argue that internal audit function that is relatively well funded has a greater monitoring ability to detect and deter material misstatements. Increased resources enable the internal audit department to hire and retain more competent personnel.

The MCCG 2007 supports the roles and responsibilities of the internal audit function. The board should set up an internal audit function, which is directly accountable to the audit committee, to recognise and manage risks. Investment in the internal audit function implies more competent internal audit function personnel can help management to establish stronger controls over financial reporting, thus reducing the existence of control problems (Lin, Pizzini, Vargus \& Bardhan, 2011). Yasin and Nelson (2012) find a positive relationship between external audit quality and cost of internal audit function. Further, Prawitt et al. (2009) find a significant association between internal audit function and absolute abnormal accruals. Thus, we hypothesize that:

$H_{5}$ Investment in internal audit function is negatively associated with discretionary accruals

\subsection{Sourcing Arrangement of Internal Audit Function}

Internal audit function can be undertaken in-house by the internal audit department in the company or outsourced to other professional companies. Outsourced internal audit refers to internal audit services that are undertaken by independent accounting firms (Carcello, Hermanson \& Raghunandan, 2005; Desai, Gerard \& Tripathy, 2011). According to Bursa Malaysia, listed companies are required to disclose whether their internal audit function is performed in-house or is outsourced. Some studies have found the in-house internal audit function leads to greater internal monitoring and control over audit operations, thereby protecting proprietary information, providing better understanding of business processes and associated risks from outsiders and nonemployees as well as learning opportunities for the company's own employees compared to an outsourced internal audit function (Vecchio \& Clinton, 2003; Rittenberg, 1999). The benefits of in-house audit function are due to in-depth knowledge, loyalty and role in handling crisis situations, such as those involving fraud (Spekle, Elten \& Kruis, 2007).

On the other hand, advocates of outsourced internal audit function argue that in-house internal auditors are less independent than outsourced internal auditors as it is difficult for an employee to be truly independent from the management (James, 2003; Ahlawat \& Lowe, 2004). There are external auditors who consider internal auditors to be more objective and independent when the internal auditors are not employees of the company (Gramling \& Hermanson, 2006). Johl, Johl, Subramaniam \& Cooper (2013) find the internal audit function increases discretionary accruals when this function is outsourced, but the in-house internal audit function decreases the level of discretionary accruals. The above discussion leads to the hypothesis that:

$\mathrm{H}_{6}$ : Sourcing arrangement of internal audit function is associated with discretionary accruals

\subsection{Big4 Audit Firm}

Big 4 audit firms are commonly used as proxy of audit quality which is considered as an external monitoring mechanism (Fan \& Wong, 2005). Davidson et al. (2005) argue that Big4 audit firms affect earnings quality positively with respect to earnings management activity detection due to higher expertise and resources that Big4 audit firms have relative to their smaller counterparts. Thus, we hypothesize that:

$H_{7}$ : Companies which are audited by Big4 audit firms are negatively associated with discretionary accruals

\subsection{Audit Fees}

An audit fees, as a proxy of audit quality, is an important external monitoring mechanism to mitigate earnings management (high earnings quality). Frank, Johnson and Nelson (2002) find that an audit fees is associated with smaller discretionary accruals. Also, Larcker and Richardson (2004) find that strong governance mitigates the negative relationship between audit fees and accruals. Gul, Chen \&Tsui (2003) find positive relationship between audit fees and 
discretionary accruals. Antle, Gordon, Narayanamoorthy \& Zhou (2006) find audit fees leads to high abnormal accruals. Additionally, Hasnan, Rahman \& Mahenthiran (2012) show evidence that audit fees is positively related to fraudulent financial reporting in Malaysia. Thus, we hypothesize that:

$H_{8}$ : Audit fees for external audit are negatively associated with discretionary accruals

\subsection{Non-Audit Services Fees}

More investment in non-audit services could increase audit quality by increasing an auditor's ability to detect earnings management (Dechow \& Schrand, 2010). Antle et al. (2006) find non-audit services fees decreases the level of abnormal accruals. While, Frankel et al. (2002) find that non-audit services fees is associated with higher discretionary accruals. Thus, we hypothesizes that:

\section{$H_{9}:$ Non-audit services fees for external audit are negatively associated with discretionary accruals}

\subsection{Ownership Concentration}

Ownership concentration is said to be a source of agency problems because higher ownership concentration provides more power to a limited number of shareholders, who in turn might expropriate minority shareholders' interests (Porta, et al., 1999). Fan and Wong (2002) report that ownership concentration is related to low earnings quality. Yunos, et al. (2010) find ownership concentration is associated with lower accounting conservatism. Another study by Kamardin and Haron (2011) suggests effective monitoring mechanisms through concentrated ownership in Malaysian companies whereby there is interest alignment between the majority and minority shareholders. However, Abdullah and Nasir (2004); and Abdul Rahman and Ali (2006) provide evidence on the possible influence of concentrated ownership on board independence in relation to earnings management. Following the agency theory, this study hypothesizes that:

$$
H_{10} \text { : Ownership concentration is positively associated with discretionary accruals }
$$

\section{Research Method}

The population of the study is 822 firms in year 2012 listed on the Main Market of Bursa Malaysia. The period of study covers four years (from 2009 to 2012). The study includes the year 2009 because it is the first year full disclosure for the cost of investment in internal audit function is made as required by the Bursa Malaysia. We follow previous studies by excluding finance-related companies and unit trusts (Yatim, Kent\& Clarkson, 2006; Yunos, et al., 2010); firms with incomplete online annual reports for the period between 2009 and 2012; and firms which have missing data of study variables. The final sample of the study is 508 firms. Data were collected from Data Stream and annual reports available on the Bursa Malaysia website. Table 1 provides a breakdown of the sample by industries.

Table 1. Sample of Study by Industries

\begin{tabular}{cccc}
\hline Industries & Firms & Observations & Percentage \\
\hline Construction & 30 & 120 & 6 \\
Consumer & 83 & 332 & 16 \\
Industrial products & 163 & 652 & 32 \\
Plantation & 33 & 132 & 6 \\
Property & 49 & 196 & 10 \\
Technology & 23 & 92 & 5 \\
Trading and Services & 127 & 508 & 25 \\
\hline Total & $\mathbf{5 0 8}$ & $\mathbf{2 , 0 3 2}$ & $\mathbf{1 0 0}$
\end{tabular}

\subsection{Measurement of Discretionary Accruals}

Discretionary accruals are used as proxy for earnings quality. Two measurements of discretionary accruals are used in this study to see whether the results are consistent for all the models. The first measurement (DA1) follows the modified Jones model by Dechow, Sloan and Sweeney (1995) which has been widely used in previous studies. Ordinary-Least 
Squares (OLS) cross-sectional regression for all study years and industries are used to estimate the fitted values (coefficients of $\mathrm{a}_{1}, \mathrm{a}_{2}$, and $\mathrm{a}_{3}$ ). The equation to calculate total accruals is as follows:

$A_{C C} / T A_{t-1}=a_{0}+a_{1}\left(1 / T A_{t-1}\right)+a_{2}\left(\Delta R E V-\Delta R E C / T A_{t-1}\right)+a_{3}\left(P P E / T A_{t-1}\right)+e_{t}(1)$

Where:

$\mathrm{ACC}_{\mathrm{t}}=$ total accruals measured by net income - cash flows from operations

$\mathrm{TA}_{\mathrm{t}-1}=$ prior total assets

$\triangle R E V=$ change in sales/revenue

$\triangle \mathrm{REC}=$ change in trade receivables

$\mathrm{PPE}=$ property, plant and equipment

$e_{t}=$ error term.

Following Dechow et al. (1995), the change in accounts receivable is deducted from the change in revenues before estimation. Then, the industry- and year-specific is used to estimate the parameter estimates (coefficients $a_{0} ; a_{1} ; a_{2} ;$ and a3) to infer non-discretionary accruals (NDA) as in equation (2):

$N D A_{t}=a_{0}+a_{1}\left(1 / T A_{t-1}\right)+a_{2}\left(\Delta R E V-\triangle R E C / T A_{t-1}\right)+a_{3}\left(P P E / T A_{t-1}\right)(2)$

The difference between estimation (standardized residuals) in equation (2) and actual accruals represents the total discretionary accruals in the following equation:

$D A_{t}=A C C_{t}-N D A_{t}$

Where:

$\mathrm{NDA}=$ non-discretionary accruals

$\mathrm{DA}=$ discretionary accruals from the residual estimated from model 1

The second measurement of discretionary accruals (DA2) follows the modified Jones model by Yoon et al. (2006). Studies in Korea by Yoon et al. (2006); and in Bangladesh by Islam, Ali and Ahmed (2014) find that the modified Jones model by Dechow et al. (1995) does not robust for Asian companies. The model (DA2) is described in equation (4):

$\mathrm{TA}_{t} / R E V_{t}=\beta_{0}+\beta_{1}\left(\Delta \mathrm{REV}_{\mathrm{t}}-\Delta \mathrm{REC} \mathrm{C}_{\mathrm{t}}\right) / \mathrm{REV}_{\mathrm{t}}+\beta_{2}\left(\Delta \mathrm{EXP}_{\mathrm{t}}-\Delta \mathrm{PA} \mathrm{Y}_{\mathrm{t}}\right) / \mathrm{REV}_{\mathrm{t}}+\beta_{3}\left(\mathrm{DEP}_{\mathrm{t}}+\mathrm{RET}_{\mathrm{t}}\right) / \mathrm{REV}_{\mathrm{t}}+\mathrm{e}_{t}(4)$

Where:

$\triangle E X P=$ change in sum of cost of goods sold and selling and general administrative expenses excluding non-cash expenses.

$\triangle \mathrm{PAY}=$ change in accounts payable

$\mathrm{DEP}=$ depreciation expenses

$\mathrm{RET}=$ retirement benefits expenses

Yoon et al.'s (2006) model proposes that the total accruals are related to changes in the cash revenue/sales, change of cash expenses and non-cash expenses of depreciation expenses and the expenses of retirement benefits. Discretionary accruals are accruals minus non-discretionary accruals for each observation as follows:

$\mathrm{DA}_{\mathrm{t}}=\mathrm{TA}_{\mathrm{t}} / \mathrm{REV} \mathrm{V}_{\mathrm{t}}\left[\beta_{0}+\beta_{1}\left(\Delta \mathrm{REV} \mathrm{V}_{\mathrm{t}}-\Delta \mathrm{REC} \mathrm{C}_{\mathrm{t}}\right) / \mathrm{REV}_{\mathrm{t}}+\beta_{2}\left(\Delta \mathrm{EXP}_{\mathrm{t}}-\Delta \mathrm{PAY} \mathrm{t}\right) / \mathrm{REV}_{\mathrm{t}}+\beta_{3}\left(\mathrm{DEP}_{\mathrm{t}}+\mathrm{RET}_{\mathrm{t}}\right) / \mathrm{REV}_{\mathrm{t}}\right]$ (5)

The absolute value of discretionary accruals $|D A|$ represents earnings management because earnings management can be income-increasing or income-decreasing accruals. Bedard and Johnstone (2004); Klein (2002); and Abdul Rahman and Ali (2006) suggest that the absolute value of abnormal accruals is a good proxy for the combined effect of income-increasing and income-decreasing earnings management. Thus, the high absolute value of discretionary accruals indicates low earnings quality and vice versa.

Table 2 shows that the extended model of Yoon et al. (2006) is significant at the $1 \%$ level and it has an explanatory power of $47.54 \%$ which is more than Dechow et al.'s (1995) model of $0.81 \%$. The $\mathrm{R}^{2}$ shows that the model by Yoon et al.(2006) has more explanatory power to capture the discretionary accruals of Malaysian Main Market listed companies.

Table 2. Multiple Regression Results of Discretionary Accruals

\begin{tabular}{|c|c|c|c|c|c|}
\hline \multirow{2}{*}{ Variables } & \multicolumn{2}{|c|}{ M-Jones by Dechow et al. (1995) } & \multicolumn{3}{|c|}{ Extended M-Jones by Yoon et al. (2006 ) } \\
\hline & Coef. & t-stat & Variables & Coef. & t-stat \\
\hline cons & -0.0110 ** & -2.31 & cons & 0.0852 & 1.57 \\
\hline$\overline{1} / \mathrm{TA}$ & -485.35 & -1.31 & $(\triangle \mathrm{REV}-\Delta \mathrm{REC}) / \mathrm{REV}$ & $-0.0924^{\star \star *}$ & -19.91 \\
\hline$(\triangle \mathrm{REV}-\Delta \mathrm{REC}) / \mathrm{TA}$ & 0.0112 & 1.06 & $(\triangle \mathrm{EXP}-\triangle \mathrm{PAY}) / \mathrm{REV}$ & $0.1321^{\star \star \star}$ & 23.50 \\
\hline PPE /T A & $-0.0346 * * *$ & -3.78 & (DEP + RET) / REV & $-3.8545^{\star \star \star}$ & -29.95 \\
\hline F-value & \multicolumn{2}{|c|}{5.25} & & \multicolumn{2}{|c|}{613.74} \\
\hline Sig & \multicolumn{2}{|c|}{0} & & \multicolumn{2}{|c|}{0} \\
\hline R-squared & \multicolumn{2}{|c|}{0.0081} & & \multicolumn{2}{|c|}{0.4754} \\
\hline $\mathrm{N}$ & \multicolumn{2}{|c|}{2032} & & \multicolumn{2}{|c|}{2032} \\
\hline
\end{tabular}


Hence, the model of Yoon et al. (2006) is used as (DA2) the second measurement of discretionary accruals (proxy of earnings quality) in this study.

\subsection{Discretionary Accruals Model Specification}

Specifically, this study attempts to examine the relationship between audit committee characteristics (size, independence, frequency of meetings, financial expertise and chairman being former audit partner), internal audit function, Big4 audit firm, audit and non-audit services fees, ownership concentration and earnings quality. In addition, following previous studies, we include firm size, return on assets, leverage, income loss and sales growth as control variables (Ismail et al., 2009; Peasnell, Pope \& Young, 2005; Abdul Rahman \& Ali, 2006; Dechow, Richardson \& Tuna, 2003). Additionally, we include years and industries as dummy variables to control business cycle effects and differences across industries (Datta, Iskandar-Datta \& Singh, 2013). The model to achieve the objectives is listed below:

$$
|D A|=\beta_{1} \text { ACSIZE }+\beta_{2} \text { ACIND }+\beta_{3} \text { ACMEET }+\beta_{4} \text { ACEXPERT }+\beta_{5} \text { ACPART }+\beta_{6} \text { IAFINVE }+\beta_{7} \text { IAFSOUR }+\beta_{8} B I G 4
$$

$+\beta_{9} A F+\beta_{10} N O N A F+\beta_{11}$ OWCO $+\beta_{12}$ ROA $+\beta_{13} L E V+\beta_{14} F S I Z E+\beta_{15} L O S S+\beta_{16}$ SGROWTH $+e$

Where:

$|\mathrm{DA}|=$ absolute value of discretionary accruals

ACSIZE = audit committee size

ACIND = audit committee independence

ACMEET = audit committee meeting

ACEXPERT = audit committee financial expertise

ACPART = audit committees' chairman former audit partner

IAFINVE = cost of internal audit function

IAFSOUR = internal audit function sourcing arrangement

BIG4 = big 4 audit firm

$\mathrm{AF}=$ external audit fees

NONAF = external non-audit services fees

OWCO5 = ownership concentration

$\mathrm{ROA}=$ return on assets

$\mathrm{LEV}=$ leverage

FSIZE $=$ firm size

LOSS $=$ net income loss

SGROWTH = sales growth

Table 3 provides a summary of measurements of variables used in the study.

Table 3. Summary of Measurement of Study Variables

\begin{tabular}{ll}
\hline Variables & Measurement \\
\hline ACIND & Percentage of total number of independent non-executive directors divided by the total number of AC members (Abdul \\
& Rahman \& Ali, 2006; Mohamad et al., 2012). \\
ACSIZE & Total number of audit committee members (Saleh et al., 2007). \\
ACEXPERT & The ratio of audit committee members with accounting and financial knowledge to total members of AC (Saleh et al., 2007; \\
& Goh 2009; Zaman et al., 2011). \\
ACPART & The chairman of audit committee who was previously a senior auditor in audit firm (senior manager or partner) (Yusof, 2010). \\
ACMEET & Frequency of audit committee meetings (Saleh et al., 2007; Xie, et al., 2003; Zaman et al., 2011). \\
IAFINVE & The natural log of internal audit cost (Johl, et al., 2013). \\
IAFSOUR & Equals "1", if IAF is established in-house and "0" otherwise (Johl, et al., 2013). \\
BIG4 & Equals "1" if the firm is audited by Big4 Auditors; and "0" otherwise (Abdul Rahman \& Ali, 2006; Davidson et al., 2005). \\
AF & The natural log of external audit fees (Frankel et al., 2002; Antle et al., 2006). \\
NONAF & The natural log of external non-audit services fees (Frankel et al., 2002; Antle et al., 2006). \\
OWCO & Ownership by largest five shareholders (Gedajlovic \& Shapiro, 2002). \\
FSIZE & Natural log of total assets (Ismail et al., 2009; Peasnell et al., 2005; Abdul Rahman \& Ali, 2006). \\
LEV & The ratio of total liabilities to total assets (Klein, 2002; Davidson et al., 2005). \\
ROA & The annual net profit of individual firm before tax divided by total assets (Abdul Rahman \& Ali, 2006; Ismail et al., 2009). \\
LOSS & Dummy variable equal to"1" if the net income is less than zero and "0" otherwise (Dechow et al., 2003). \\
SGROWTH & Sales growth, annual sales growth (current year sales - prior year's sales)/prior year's sales (Ahmed, Billings Morton \& \\
\hline
\end{tabular}




\section{Descriptive Statistics and Analysis}

Table 4 provides descriptive statistics of the continuous variables while Table 5 provides descriptive statistics of the dichotomous variables. Table 4 shows the average size of audit committee of Malaysian Main Market companies is three members. A total of $88 \%$ of the audit committee members are independent directors. An average (Mean) of $47.47 \%$ of the audit committee members have financial expertise. There is an increase in audit committee independence and audit financial expertise compared to findings in Yunos et al. (2010) of 70\% and 37\%, respectively, using data from 2001 to 2007. This increase in audit committee independence follows the recommendation of the MCCG that independent directors should dominate the audit committee. Furthermore, the minimum value of $67 \%$ for audit committee independence indicates that the audit committee is dominated by independent directors.

Table 4. Descriptive Statistics of Continuous Variables

\begin{tabular}{c|cccccc}
\hline Variable Name & Minimum & Maximum & Mean & S.Dev. & Skewness & Kurtosis \\
\hline DA1 & 0.002 & 0.195 & 0.056 & 0.050 & 1.266 & 4.028 \\
DA2 & 0.007 & 1.452 & 0.256 & 0.338 & 2.258 & 7.801 \\
ACSIZE & 3.000 & 5.000 & 3.237 & 0.473 & 1.815 & 5.456 \\
ACIND & 0.667 & 1.000 & 0.885 & 0.150 & -0.581 & 1.423 \\
ACMEET & 4.000 & 10.000 & 4.992 & 1.082 & 2.000 & 8.468 \\
ACEXPERT & 0.200 & 1.000 & 0.475 & 0.202 & 0.910 & 3.013 \\
IAFINV (log) & 8.923 & 15.607 & 11.408 & 1.350 & 0.808 & 3.433 \\
AF (log) & 10.731 & 13.724 & 11.927 & 0.799 & 0.602 & 2.663 \\
NONAF (log) & -9.210 & 12.763 & 6.009 & 8.051 & -1.298 & 2.827 \\
OWCO & 17.850 & 85.730 & 54.241 & 15.735 & -0.161 & 2.318 \\
ROA & -0.599 & 0.337 & 0.033 & 0.093 & -0.892 & 6.647 \\
LEV & 0.004 & 1.652 & 0.391 & 0.220 & 0.997 & 5.710 \\
FSIZE (log) & 10.402 & 17.453 & 12.897 & 1.440 & 0.863 & 3.692 \\
SGROWTH & -0.593 & 1.581 & 0.071 & 0.337 & 1.818 & 9.254 \\
\hline
\end{tabular}

The average number of meetings for the audit committee in the majority of companies is about 4.99which is more than what is recommended by the MCCG, i.e., to meet at least four times annually. The average investment on internal audit function is 11.41 (RM370,658) with the minimum value being8.92 (RM3,000) and the maximum value being15.61 (RM39,000,000). These results indicate that there is a concerted effort towards investment in internal audit function to increase earnings quality and to enhance the quality of financial reporting in Malaysian Main Market listed companies. The average external audit fees is 11.93 (RM284,136) and the average non-audit services fees is 6.01 (RM97,310). An average of $54.24 \%$ of the firms' shares is concentrated among the largest five shareholders in Malaysia Main Market companies which means that majority of the shares is in the hands of a few shareholders (high ownership concentration).

In terms of the controlled variables, the size of companies varies with a minimum of 10.4 and a maximum of 17.45 . The sample has an average leverage level of $39 \%$ and ROA of 3.3\%. Some of the companies have losses. The average of sales growth is $7 \%$ and some have negative value which indicates revenue in current year is less than previous year.

Table 5. Descriptive Statistics of Dichotomous Variables

\begin{tabular}{cccccc}
\hline \multirow{2}{*}{ Variable Name } & \multirow{2}{*}{ Observations } & \multicolumn{2}{c}{ Frequency } & \multicolumn{2}{c}{ Percentage } \\
\hline IAFSOUR & 2032 & $\mathbf{1}$ & $\mathbf{0}$ & $\mathbf{1}$ & $\mathbf{0}$ \\
ACPART & 2032 & 655 & 1,095 & $46.10 \%$ & $53.90 \%$ \\
BIG4 & 2032 & 1135 & 89737 & $32.20 \%$ & $67.80 \%$ \\
LOSS & 2032 & 438 & 1,594 & $55.90 \%$ & $44.10 \%$ \\
\hline
\end{tabular}

Table 5 indicates that $46.2 \%$ of Main Market listed companies in Malaysia have in-house internal audit function and $53.8 \%$ of the companies outsource their internal audit function. The finding also indicates that $32.3 \%$ of Malaysian companies have audit committee chairman who was an audit partner. A total of 1,135 companies or $55.7 \%$ are audited by Big4 audit firms while another $44.3 \%$ (901 companies) are audited by non-Big 4 audit firms. The statistics also indicate that $21.5 \%$ of the companies have net income loss.

Following previous studies (e.g., Saleh et al., 2007; Yoon et al., 2006; Ball \& Shivakumar, 2005; Kraft, Lee \& 
Lopatta, 2014; Bonetti, Parbonetti \& Magnan, 2013; Gaio, 2010; Kothari, Leone \& Wasley, 2005; Prawitt et al., 2009), winsorized distributions were conducted to eliminate possible outliers in all continuous variables at the top and bottom one percent of the data distribution to maintain the characteristics of original data. Robust standard errors were conducted to estimate the regression models to solve heteroskedasticity problem. Skewness and kurtosis were used to test the normality assumption; for skewness, Hair, Tatham, Anderson and Black (2006) suggest a higher threshold of \pm 3 ; for kurtosis, Kline (1998) suggests a higher threshold of \pm 10 . The results from this approach (see Table 4 and Table 5) led to the conclusion that the data set has no serious violation of the normality assumption. The correlation matrix between variables using Pearson correlation was conducted to test for multicollinearity issue. As presented in Table 6, no correlation exits of more than 0.80 (Hair et al., 2006); thus multicollinearity is not an issue in this study.

Table 6. Correlations Matrix of Study Variables

\begin{tabular}{|c|c|c|c|c|c|c|c|c|c|c|c|c|c|}
\hline & & 1 & 2 & 3 & 4 & 5 & 6 & 7 & 8 & 9 & 10 & 11 & 12 \\
\hline 1 & DA1 & 1 & & & & & & & & & & & \\
\hline 2 & DA2 & $0.25^{\star \star \star}$ & 1 & & & & & & & & & & \\
\hline 3 & ACSZIE & 0.0145 & 0.0147 & 1 & & & & & & & & & \\
\hline 4 & ACIND & -0.0348 & 0.0310 & -0.1431 & 1 & & & & & & & & \\
\hline 5 & ACMEET & 0.0037 & 0.0674 & 0.0981 & 0.0458 & 1 & & & & & & & \\
\hline 6 & ACEXPERT & -0.0014 & -0.0226 & $-0.14^{*}$ & 0.0508 & 0.0129 & 1 & & & & & & \\
\hline 7 & ACPART & 0.0289 & 0.0252 & -0.0171 & 0.0054 & 0.0423 & 0.1244 & 1 & & & & & \\
\hline 8 & IAFSOU & -0.0711 & -0.0440 & $0.17^{\star *}$ & 0.0716 & 0.0938 & -0.0449 & -0.0508 & 1 & & & & \\
\hline 9 & IAFINV & -0.0948 & -0.0887 & $0.27^{\star \star \star}$ & -0.0055 & $0.25^{\star \star \star}$ & -0.0572 & -0.0406 & $0.64^{\star \star \star}$ & 1 & & & \\
\hline 10 & BIG4 & -0.1126 & -0.0662 & 0.0948 & -0.0390 & 0.0371 & -0.0530 & 0.0406 & $0.17^{\star *}$ & $0.32^{\star * \star}$ & 1 & & \\
\hline 11 & $\mathrm{AF}$ & -0.0940 & -0.0699 & $0.23^{\star \star \star}$ & 0.0412 & $0.24^{\star \star \star}$ & -0.0928 & -0.0133 & $0.44^{\star \star \star}$ & $0.71^{\star \star *}$ & $0.28^{\star * \star}$ & 1 & \\
\hline 12 & NAF & -0.0713 & -0.0459 & 0.0775 & -0.0059 & 0.0580 & 0.0235 & 0.0141 & 0.0596 & $0.23^{\star \star \star}$ & $0.23^{\star \star \star}$ & $0.19 * *$ & 1 \\
\hline 13 & OWCO & 0.0163 & 0.0316 & 0.1097 & -0.1123 & 0.0248 & 0.0075 & -0.0142 & 0.0687 & 0.1222 & $0.15^{\star}$ & -0.0010 & 0.0222 \\
\hline 14 & ROA & $-0.18^{\star *}$ & -0.19 ** & 0.1047 & 0.0016 & -0.0681 & 0.0095 & 0.0083 & 0.0868 & $0.16^{* *}$ & $0.18 * \star$ & 0.1005 & 0.1294 \\
\hline 15 & LEV & 0.1183 & 0.0114 & 0.0379 & 0.0230 & 0.1274 & -0.0320 & -0.0022 & 0.0362 & 0.1105 & -0.1268 & $0.22^{\star \star \star}$ & -0.0779 \\
\hline 16 & FSIZE & -0.1254 & -0.0485 & $0.25^{\star \star \star}$ & 0.0338 & $0.23^{\star \star \star}$ & -0.1234 & -0.0099 & $0.44^{\star \star \star}$ & $0.76^{\star \star \star}$ & $0.35^{\star \star \star}$ & $0.79^{* \star *}$ & $0.22^{\star \star \star}$ \\
\hline 17 & LOSS & $0.15^{\star}$ & $0.16^{\star \star}$ & -0.0509 & 0.0412 & 0.0593 & -0.0046 & 0.0072 & -0.0936 & $-0.17^{\star \star}$ & $-0.16^{\star \star}$ & $-0.14^{*}$ & -0.0814 \\
\hline \multirow[t]{2}{*}{18} & SGROWTH & 0.0398 & -0.0825 & 0.0309 & 0.0449 & 0.0192 & 0.0105 & -0.0235 & 0.0390 & 0.0320 & 0.0119 & 0.0606 & 0.0352 \\
\hline & & 13 & 14 & 15 & 16 & 17 & 18 & & & & & & \\
\hline 13 & OWCO & 1 & & & & & & & & & & & \\
\hline 14 & ROA & $0.15^{\star}$ & 1 & & & & & & & & & & \\
\hline 15 & LEV & $-0.14^{*}$ & $-0.32^{\star \star \star}$ & 1 & & & & & & & & & \\
\hline 16 & FSIZE & 0.1136 & $0.18^{\star *}$ & $0.18^{\star *}$ & 1 & & & & & & & & \\
\hline 17 & LOSS & -0.1285 & $-0.66^{\star \star *}$ & $0.27^{\star \star *}$ & $-0.22^{\star \star \star}$ & 1 & & & & & & & \\
\hline 18 & SGROWTH & -0.0009 & $0.19^{\star \star}$ & 0.0375 & 0.0704 & $-0.17^{\star \star}$ & 1 & & & & & & \\
\hline
\end{tabular}

Note: ${ }^{*},{ }^{*},{ }^{* * \star}$, significant level at $10 \%, 5 \%$ and $1 \%$, respectively. DA1 = Discretionary accruals modified Jones model (Dechow et al., 1995), DA2 = Extended of modified Jones model by (Yoon et al., 2006), ACSIZE = AC size, ACIND = AC independence, ACMEET = AC meeting, ACEXPERT $=$ AC financial expertise, ACPART =AC chairman audit partner, IAFSOU = sourcing arrangements of internal audit function, IAFINV= investment in internal audit function, BIG4 = largest 4 audit firms, AF = external audit fees, NAF= external non-audit services fees, OWCO = Ownership Concentration, ROA = Return on assets, LEV = Leverage, FSIZE = Firm size, LOSS = Net Income Loss, SGROWTH = Sales Growth.

\section{Results and Discussion}

The OLS regression was used to analyse the data. For the first dependent variable (DA1), the model is fit and significant at $1 \%$ level (with F-value $=6.22, R^{2}=0.0792$ ); and for the second dependent variable (DA2), the model is also fit and significant at $1 \%$ level (with F-value $=18.13, R^{2}=0.2577$ ). 
Table 7. Multiple Regression Results

\begin{tabular}{|c|c|c|c|c|c|}
\hline \multicolumn{6}{|c|}{$\begin{array}{c}|\mathrm{DA}|=\beta_{1} \text { ACSIZE }+\beta_{2} \text { ACIND }+\beta_{3} \text { ACMEET }+\beta_{4} \text { ACEXPERT }+\beta_{5} \text { ACPART }+\beta_{6} \text { IAFINVE }+\beta_{7} \text { IAFSOUR }+\beta_{8} \text { BIG }+\beta_{9} \text { AF }+\beta_{10} \\
\text { NONAF }+\beta_{11} \text { FSIZE }+\beta_{12} \text { ROA }+\beta_{13} L E V+\beta_{14} \text { OWCO }+\beta_{15} \text { LOSS }+\beta_{16} S G R O W T H+e\end{array}$} \\
\hline \multirow{2}{*}{ Variables } & \multirow{2}{*}{$\begin{array}{l}\text { Predicted } \\
\text { Sign }\end{array}$} & \multicolumn{2}{|c|}{ DA1 } & \multicolumn{2}{|c|}{ DA2 } \\
\hline & & Coef. & t-stat. & \multirow{2}{*}{$\frac{\text { Coef. }}{0.362^{\star \star *}}$} & \multirow{2}{*}{ t-stat. } \\
\hline cons & $?$ & $0.0838^{\star \star \star}$ & 3.94 & & \\
\hline$\overline{A C S I Z E}$ & - & $0.0046^{*}$ & 1.83 & 0.0186 & 1.22 \\
\hline ACIND & - & -0.0063 & -0.86 & 0.0449 & 1.04 \\
\hline ACMEET & - & 0.0002 & 0.21 & $0.0238^{* * *}$ & 3.64 \\
\hline ACEXPERT & - & -0.0040 & -0.73 & -0.0374 & -1.14 \\
\hline ACPART & - & $0.00389^{*}$ & 1.66 & 0.0201 & 1.40 \\
\hline IAFSOUR & ? & -0.0026 & -0.90 & $0.0316^{*}$ & 1.73 \\
\hline IAFINVE & - & 0.0010 & 0.64 & $-0.0294^{\star \star *}$ & -2.88 \\
\hline BIG4 & - & \multirow{2}{*}{$\begin{array}{l}-0.0035 \\
-0.0021\end{array}$} & -1.44 & -0.00758 & -0.50 \\
\hline $\mathrm{AF}$ & - & & -0.92 & $-0.0267^{*}$ & -1.68 \\
\hline NONAF & - & -0.0001 & -0.73 & & -1.50 \\
\hline OWCO & + & $0.0002^{\star \star \star}$ & 3.05 & \multirow{2}{*}{0.000123} & 0.28 \\
\hline $\mathrm{ROA}$ & - & $-0.0696^{* \star *}$ & -2.71 & & -3.87 \\
\hline LEV & + & $0.0176^{\star \star \star}$ & 2.74 & $\begin{array}{l}-0.664^{\star \star \star x} \\
0.00675\end{array}$ & 0.17 \\
\hline FSIZE & - & $-0.0030^{* *}$ & -2.02 & 0.0150 & 1.49 \\
\hline LOSS & + & 0.0035 & 0.92 & 0.0451 & 1.64 \\
\hline SGROWTH & + & $0.0108^{\star \star \star}$ & 2.76 & -0.0401 & -1.58 \\
\hline Years Dummy & ? & & & & \\
\hline Ind. Dummy & ? & & & & \\
\hline F-value & & & & & \\
\hline Sig & & & & & \\
\hline R-squared & & & & & \\
\hline $\mathrm{N}$ & & & & & \\
\hline $\begin{array}{l}\text { Note: }{ }^{*},{ }^{* *},{ }^{* *} \text { significa } \\
\text { Dechow et al., } 1995, \square \\
\text { ACMEET = AC meetin } \\
\text { arrangements of interr } \\
\text { audit fees, NAF= exter }\end{array}$ & $\%$, and $1 \%$ & ectively. DA1 & $\begin{array}{l}\text { Ionary } \\
\text {;ACSIZ } \\
\text { airman }\end{array}$ & der modifie & $\begin{array}{l}\text { odel by } \\
\text { endence, } \\
\text { = sourcing } \\
\text { external } \\
\text { everage, }\end{array}$ \\
\hline
\end{tabular}

Table 7 shows that ACSIZE is positively significant with DA1 $(t=1.83, p<0.10)$ but not significant with DA2. This result does not support the agency theory and resource dependence theory which suggests that larger audit committees would effectively monitor and bring more external resources to enhance financial reporting quality.

Audit committee meetings (ACMEET) is found to be significant with positive relationship with discretionary accruals (DA2) $(t=3.64, p<0.01)$, but not significant with DA1. This result contradicts $\mathrm{H}_{3}$ which proposes an increase in ACMEET decreases the level of discretionary accruals. Also, this result is in contrast with the arguments of the agency and resource dependence theories that an increase in the frequency of audit committee meetings can enhance internal monitoring and increase the transparency of financial reporting by exploiting directors' expertise during the meetings. The possible explanation might be due to the fact that high ownership concentration affects directors' independence and leads to ineffective audit committee meetings.

ACPART is found to be in a significantly positive relationship with DA1 but not with DA2. The significant relationship indicates that the discretionary accruals (DA1) is increasing in the companies which have audit committee chairman who is a senior or former audit partner. This finding contradicts the hypothesis.

The results also show insignificant association between sourcing arrangements (IAFSOUR) and DA1, but a significant and positive association with DA2. The explanation of this result could be the in-house internal audit function (IAF) leads to increased discretionary accruals. This result suggests that outsourced IAF is more expertise compared to in-house IAF. In addition, outsourced IAF is considered as more independent and able to fulfil the monitoring role better than the in-house IAF (Johl, et al., 2013).

The cost of internal audit function (IAFINVE) is insignificant with DA1 but significant and negatively related to DA2 at the $1 \%$ level. This finding somehow indicates that increasing the cost of IAFINVE would increase internal monitoring by reducing the earnings management and lead to higher earnings quality. This result supports increasing investment in 
internal audit function as a source to enhance internal monitoring.

The association between external audit fees (AF) and DA1 is not significant but it is negatively significant with DA2 $(t=1.68, p<0.10)$. This supports the hypothesis that high audit fees can be a proxy of audit quality and subsequently, enhanced earnings quality. However, no significant relationship appears between external non-audit services fees (NONAF) with DA1 and DA2. In terms of ownership concentration (OWCO), the coefficient is significantly positive with DA1 ( $t=3.05, p<0.01)$, but insignificant with DA2. This result suggests the influence of OWCO on earnings quality which supports the agency theory.

The insignificance of independent directors on the audit committee for both measurements (DA1 and DA2) implies that the independent directors on the audit committee are ineffective in overseeing the influence of the financial reporting process on earnings quality. Thus, $\mathrm{H}_{2}$ is not supported. The finding could be justified by the nature of the job undertaken by the independent directors in terms of the committees they serve. In addition, the result indicates that audit committee expertise (ACEXPERT) is not related to earnings quality. The possible explanation might be due to lack of independence (Defond, Hann \& Hu, 2005). The Big4 audit firm also has no significance with DA1 and DA2.

For control variables, the ROA coefficient is significantly negative with both DA1 and DA2 at the $1 \%$ level. The current study finds that firm performance is positively related to earnings quality. This is consistent with Abdul Rahman and Ali (2006) who argue firms with low performance have the tendency to engage in earnings management. Meanwhile, Leverage (LEV) is found to have significantly positive relationship with DA1 at the $1 \%$ level, indicating that higher leveraged firms are more motivated to engage in earnings manipulation in order to avoid debt covenant violation. In other words, higher leverage leads to a higher level of earnings manipulation. Firm size (FSIZE) is negatively significant with DA1 at the 1\% level, indicating that large firms report higher quality of earnings since they are closely monitored by the financial processes in the firms. Sales growth (SGROWTH) is in a positively significant relationship with DA1 at the 10\% level, consistent with the finding in Warfield et al. (1995),indicating that increasing sales growth motivates the managers to engage in 'smoothing' earnings management. LOSS is found to be insignificant with discretionary accruals.

\section{Conclusion}

The study finds some evidence that the extended M-Jones model of Yoon et al. (2006) is robust in detecting discretionary accruals in the Malaysian Main Market listed companies. The results provide evidence that outsourcing internal audit function, more investment in internal audit function and external audit fees increase the level of earnings quality. However, the results also indicate that some audit committee characteristics (such as size, independence, meeting frequency, financial expertise and chairman being former audit partner) may not contribute to enhancing earnings quality. The study also finds ownership concentration leads to low earnings quality. External audit by Big4 audit firms and nonaudit services fees are not associated with earnings quality. However, the scope of the study is limited to the Malaysian Main Market listed companies for a period of study of four years from 2009 to 2012. Therefore, it is suggested that future research should examine other variables, such as internal auditors' characteristics and use different measurements to capture audit committee characteristics.

\section{References}

Abbott, L. J., Parker, S., \& Peters, G. F. (2004).Audit committee characteristics and restatements. Auditing: A Journal of Practice \& Theory, 23(1), 6987.

Abbott, L. J., Parker, S., Peters, G. F., \& Raghunandan, K. (2003).The association between audit committee characteristics and audit fees. Auditing: A Journal of Practice \& Theory, 22(2), 17-32.

Abdul Rahman, R. A., \& Ali, F. H. M. (2006). Board, audit committee, culture and earnings management: Malaysian evidence. Managerial Auditing Journal, 21(7), 783-804.

Abdullah, S. N., \& Nasir, N. M. (2004).Accrual management and the independence of the Boards of Directors and Audit Committees. International Journal of Economics, Management and Accounting, 12(1), 49-80.

Adiguzel, H. (2013). Corporate Governance, Family Ownership and Earnings Management: Emerging Market Evidence. Accounting and Finance Research, 2(4), p17.

Agrawal, A., \& Chadha, S. (2005). Corporate governance and accounting scandals. Journal of Law and Economics, 48(2), 371-406.

Ahlawat, S. S., \& Lowe, D. J. (2004). An examination of internal auditor objectivity: In-house versus outsourcing. Auditing: A Journal of Practice \& Theory, 23(2), 147-158.

Ahmad-Zaluki, N. A., \& Wan-Hussin, W. N. (2010).Corporate governance and earnings forecasts accuracy. Asian Review of Accounting, 18(1), 50-67.

Ahmed, A. S., Billings, B. K., Morton, R. M., \& Stanford-Harris, M. (2002). The role of accounting conservatism in mitigating bondholder-shareholder conflicts over dividend policy and in reducing debt costs. The Accounting Review, 77(4), 867-890.

Al-Shetwi, M., Ramadili, S. M., Chowdury, T. H. S., \& Sori, Z. M. (2011). Impact of internal audit function (IAF) on financial reporting quality (FRQ): Evidence from Saudi Arabia. African Journal of Business Management, 5(27), 11189-11198. 
Antle, R., Gordon, E., Narayanamoorthy, G., \& Zhou, L. (2006).The joint determination of audit fees, non-audit fees, and abnormal accruals. Review of Quantitative Finance and Accounting, 27(3), 235-266.

Ball, R., \& Shivakumar, L. (2005). Earnings quality in UK private firms: comparative loss recognition timeliness. Journal of Accounting and Economics, 39(1), 83-128.

Baxter, P., \& Cotter, J. (2009).Audit committees and earnings quality.Accounting \& Finance, 49(2), 267-290.

Bedard, J. C., \& Johnstone, K. M. (2004).Earnings manipulation risk, corporate governance risk, and auditors' planning and pricing decisions. The Accounting Review, 79(2), 277-304.

Bonetti, P., Parbonetti, A., \& Magnan, M. (2013). The Influence of Country-and Firm-Level Governance on Financial Reporting Quality: Revisiting the Evidence. CIRANO-Scientific Publications 2013s-03.

Bradbury, M., Mak, Y. T., \& Tan, S. M. (2006). Board characteristics, audit committee characteristics and abnormal accruals. Pacific Accounting Review, 18(2), 47-68.

Buchalter, S. D., \&Yokomoto, K. L. (2003).Audit committees' responsibilities and liability.CPA journal, 73(3), 18-23.

Carcello, J. V., Hermanson, D. R., \& Raghunandan, K. (2005). Factors associated with US public companies' investment in internal auditing. Accounting Horizons, 19(2), 69-84.

Chen, K. Y., \& Zhou, J. (2007). Audit Committee, Board Characteristics, and Auditor Switch Decisions by Andersen's Clients. Contemporary Accounting Research, 24(4), 1085-1117.

Datta, S., Iskandar-Datta, M., \& Singh, V. (2013).Product market power, industry structure, and corporate earnings management. Journal of Banking \& Finance, 37(8), 3273-3285.

Davidson, R., Goodwin-Stewart, J., \& Kent, P. (2005).Internal governance structures and earnings management. Accounting \& Finance, 45(2), 241267.

Dechow, P. M., Richardson, S. A., \& Tuna, I. (2003). Why are earnings kinky? An examination of the earnings management explanation. Review of Accounting Studies, 8(2-3), 355-384.

Dechow, P. M., Sloan, R. G., \& Sweeney, A. P. (1995). Detecting earnings management. Accounting Review, 193-225.

Dechow, P., Ge, W., \& Schrand, C. (2010). Understanding earnings quality: A review of the proxies, their determinants and their consequences. Journal of Accounting and Economics, 50(2), 344-401.

DeFond, M. L., Hann, R. N., \& Hu, X. (2005). Does the market value financial expertise on audit committees of boards of directors? Journal of Accounting Research, 43(2), 153-193.

Desai, N. K., Gerard, G. J., \&Tripathy, A. (2011).Internal audit sourcing arrangements and reliance by external auditors. Auditing: A Journal of Practice \& Theory, 30(1), 149-171.

Fan, J. P., \& Wong, T. J. (2002).Corporate ownership structure and the informativeness of accounting earnings in East Asia. Journal of Accounting and Economics, 33(3), 401-425.

Fan, J. P., \& Wong, T. J. (2005). Do external auditors perform a corporate governance role in emerging markets? Evidence from East Asia. Journal of Accounting Research, 43(1), 35-72.

Frankel, R. M., M. F. Johnson, and K. K. Nelson. 2002. The relation between auditors' fees for nonaudit services and earnings management. The Accounting Review 77 (Supplement): 71-105.

Gaio, C. (2010). The relative importance of firm and country characteristics for earnings quality around the world. European Accounting Review, 19(4), 693-738.

Garcia, L. S., Barbadillo, E. R., \& Perez, M. O. (2010). Audit committee and internal audit and the quality of earnings: empirical evidence from Spanish companies. Journal of Management \& Governance, 16(2), 305-331.

Garcia, L. S., Barbadillo, E. R., \& Perez, M. O. (2012). Audit committee and internal audit and the quality of earnings: empirical evidence from Spanish companies. Journal of Management \& Governance, 16(2), 305-331.

Gedajlovic, E., \& Shapiro, D. M. (2002).Ownership structure and firm profitability in Japan.Academy of Management Journal, 45(3), 565-575.

Goh, B. W. (2009). Audit Committees, Boards of Directors, and Remediation of Material Weaknesses in Internal Control. Contemporary Accounting Research, 26(2), 549-579.

Gramling, A. A., \&Hermanson, D. R. (2006). What role is your internal audit function playing in corporate governance? Internal Auditing-Boston-Warren Gorham and Lamont Incorporated, 21(6), 37.

Gul, F. A., Chen, C. J., \&Tsui, J. S. (2003).Discretionary Accounting Accruals, Managers' Incentives, and Audit Fees. Contemporary Accounting Research, 20(3), 441-464.

Hair, J. F., Tatham, R. L., Anderson, R. E., \& Black, W. (2006).Multivariate data analysis (Vol. 6). Upper Saddle River, NJ: Pearson Prentice Hall.

Hasnan, S., Rahman, R. A., \&Mahenthiran, S. (2012). Management motive, weak governance, earnings management, and fraudulent financial reporting: Malaysian evidence. Journal of International Accounting Research, 12(1), 1-27.

Hassan, M.-H., Moyes, G. D., Mohd-Sanusi, Z., \&lskandar, T. M. (2010). The Enforcement Role Of The Companies' Commission Of Malaysia. International Business \& Economics Research Journal (IBER), 9(2).

Hillman, A. J., \& Dalziel, T. (2003). Boards of directors and firm performance: Integrating agency and resource dependence perspectives. Academy of Management Review, 28(3), 383-396.

Ika, S. R., \&Ghazali, N. A. M. (2012).Audit committee effectiveness and timeliness of reporting: Indonesian evidence. Managerial Auditing Journal, 27(4), 403-424.

Islam, M. A., Ali, R., \& Ahmad, Z. (2014). Is modified Jones model effective in detecting earnings management? Evidence from a developing economy. International Journal of Economics and Finance, 3(2), p116.

Ismail, W., Adibah, W., Dunstan, K., \& Van Zijl, T. (2009). Earnings quality and corporate governance following the implementation of Malaysian code of corporate governance. Available at SSRN 1543524.

James, K. L. (2003). The effects of internal audit structure on perceived financial statement fraud prevention. Accounting Horizons, 17(4), 315-327.

Jensen, M. C., \&Meckling, W. H. (1976). Theory of the firm: Managerial behavior, agency costs and ownership structure. Journal of Financial Economics, 3(4), 305-360.

Johl, S. K., Johl, S. K., Subramaniam, N., \& Cooper, B. (2013). Internal audit function, board quality and financial reporting quality: evidence from 
Malaysia. Managerial Auditing Journal, 28(9), 1-1.

Kamardin, H., \&Haron, H. (2011). Internal corporate governance and board performance in monitoring roles: evidence from Malaysia. Journal of Financial Reporting and Accounting, 9(2), 119-140.

Klein, A. (2002). Audit committee, board of director characteristics, and earnings management. Journal of Accounting and Economics, 33(3), 375-400.

Kline, R. B. Principles and practice of structural equation modeling. 1998. Guilford, New York, NY.

Kothari, S. P., Leone, A. J., \&Wasley, C. E. (2005). Performance matched discretionary accrual measures. Journal of Accounting and Economics, 39(1), 163-197.

Kraft, A., Lee, B. S., \&Lopatta, K. (2014). Management earnings forecasts, insider trading, and information asymmetry. Journal of Corporate Finance, 26, 96-123.

Krishnamoorthy, G. (2002). A multistage approach to external auditors' evaluation of the internal audit function. Auditing: A Journal of Practice \& Theory, 21(1), 95-121.

Larcker, D. F., \& Richardson, S. A. (2004). Fees paid to audit firms, accrual choices, and corporate governance. Journal of Accounting Research, 42(3), 625-658.

Lin, J. W., Li, J. F., \& Yang, J. S. (2006).The effect of audit committee performance on earnings quality. Managerial Auditing Journal, 21(9), $921-933$.

Lin, S., Pizzini, M., Vargus, M., \&Bardhan, I. R. (2011). The role of the internal audit function in the disclosure of material weaknesses. The Accounting Review, 86(1), 287-323.

Mansor, N., Che-Ahmad, A., Ahmad-Zaluki, N. A., \& Osman, A. H. (2013). Corporate Governance and Earnings Management: A Study on the Malaysian Family and Non-family Owned PLCs. Procedia Economics and Finance, 7, $221-229$.

Menon, K., \& Williams, D. D. (2004).Former audit partners and abnormal accruals. The Accounting Review, 79(4), 1095-1118.

Mohamad, M. H. S., Rashid, H. M. A., \&Shawtari, F. A. M. (2012). Corporate governance and earnings management in Malaysian government linked companies: The impact of GLCs' transformation policy. Asian Review of Accounting, 20(3), 241-258.

Mustafa, S. T., \& Youssef, N. B. (2010).Audit committee financial expertise and misappropriation of assets. Managerial Auditing Journal, 25(3), 208225.

Naiker, V., \& Sharma, D. S. (2009). Former audit partners on the audit committee and internal control deficiencies. The Accounting Review, 84(2), 559587.

Peasnell, K. V., Pope, P. F., \& Young, S. (2005). Board monitoring and earnings management: do outside directors influence abnormal accruals?.Journal of Business Finance \& Accounting, 32(7-8), 1311-1346.

Petra, S. T. (2007). The effects of corporate governance on the informativeness of earnings. Economics of Governance, 8(2), 129-152.

Porta, R., Lopez-De-Silanes, F., \&Shleifer, A. (1999).Corporate ownership around the world. The Journal of Finance, 54(2), 471-517.

Prawitt, D. F., Smith, J. L., \& Wood, D. A. (2009).Internal audit quality and earnings management. The Accounting Review, 84(4), $1255-1280$.

Radzi, S. N. J. M., Islam, M. A., \& Ibrahim, S. (2011). Earning Quality in Public Listed Companies: A Study on Malaysia Exchange for Securities Dealing and Automated Quotation. International Journal of Economics and Finance, 3(2), 233-244.

Rittenberg, L. E. (1999). The effects of internal audit outsourcing on perceived external audit independence. Auditing: A Journal of Practice \& Theory, 18(s-1), 27-35.

Saleh, N. M., Iskandar, T. M., \&Rahmat, M. M. (2007).Audit committee characteristics and earnings management: evidence from Malaysia.Asian Review of Accounting, 15(2), 147-163.

Siagian, F. T., \&Tresnaningsih, E. (2011).The impact of independent directors and independent audit committees on earnings quality reported by Indonesian firms. Asian review of Accounting, 19(3), 192-207.

Simunic, D. 1984. Auditing, consulting, and auditor independence. Journal of Accounting Research 22: 679-702.

Spekle, R. F., van Elten, H. J., \&Kruis, A.-M. (2007). Sourcing of internal auditing: An empirical study. Management Accounting Research, 18(1), 102124.

Vafeas, N. (2005). Audit committees, boards, and the quality of reported earnings. Contemporary Accounting Research, 22(4), 1093-1122.

Vecchio, S. C., \& Clinton, B. D. (2003).Co-sourcing and other alternatives in acquiring internal auditing services. Internal Auditing-Boston-Warren Gorham and Lamont Incorporated-, 18(3), 33-39.

Warfield, T. D., Wild, J. J., \& Wild, K. L. (1995).Managerial ownership, accounting choices, and informativeness of earnings. Journal of Accounting and Economics, 20(1), 61-91.

Xie, B., Davidson, W. N., \&DaDalt, P. J. (2003). Earnings management and corporate governance: the role of the board and the audit committee. Journal of Corporate Finance, 9(3), 295-316.

Yang, J. S., \& Krishnan, J. (2005).Audit committees and quarterly earnings management. International Journal of Auditing, 9(3), $201-219$.

Yassin, F. M., \& Nelson, S. P. (2012).Audit Committee and Internal Audit: Implications on Audit Quality. International Journal of Economics, Management and Accounting, 20(2).

Yatim, P., Kent, P., \& Clarkson, P. (2006). Governance structures, ethnicity, and audit fees of Malaysian listed firms. Managerial Auditing Journal, 21(7), 757-782.

Yoon, S. S., Miller, G., \&Jiraporn, P. (2006).Earnings management vehicles for Korean firms. Journal of International Financial Management \& Accounting, 17(2), 85-109.

Yunos, R. M. (2011). The Effect of Ownership Concentration, Board of Directors, Audit Committee and Ethnicity on Conservative Accounting: Malaysian Evidence (Doctoral dissertation, Edith Cowan University).

Yunos, R. M., Smith, M., \& Ismail, Z. (2010).Accounting conservatism and ownership concentration: Evidence from Malaysia. Journal of Business and Policy Research, 5(2), 1-15.

Yusof, M. A. M. (2010). Does Audit Committee Constraint Discretionary Accruals in MESDAQ Listed Companies? International Journal of Business and Social Science, 1 (3),124-136

Zaman, M., Hudaib, M., \&Haniffa, R. (2011).Corporate Governance Quality, Audit Fees and Non-Audit Services Fees.Journal of Business Finance \& Accounting, 38(1-2), 165-197. 